\title{
UJI KESESUAIAN BERKAS SINAR-X DENGAN BERKAS KOLIMATOR PADA PESAWAT SINAR-X DI INSTALASI RADIOLOGI RSUD RADEN MATTAHER JAMBI
}

\author{
Enggel Fransiska*, Nehru, Muhammad Ficky Afrianto \\ Program Studi Fisika \\ Fakultas Sains dan Teknologi Universitas Jambi \\ Jl. Jambi-Ma. Bulian KM 15 Mendalo Darat Jambi 36361 \\ *E-mail: enggelfransiska@gmail.com
}

\begin{abstract}
The collimator test is one of the X-ray Quality Control (QC) program, one of the central point beam testing and the area of the collimator beam using the RMI unit. The purpose of the collimator test is to find out the suitability of the broad field of collimator with the area of X-ray beam in tolerance of $\leq 2 \%$ Focus Film Distance $(F F D)$ and the correspondence of the X-ray center point in tolerance $=3^{\circ}$ as determined by the Minister of Health Decree No . 1250 / SK / XII / 2009. The study was conducted using variations of FFD at 100 $\mathrm{Cm}, 90 \mathrm{Cm}, 80 \mathrm{Cm}$, on three X-ray radiation radiology radiation RSUD Raden Matther Jambi. In this study using digital radiograph unit $(D R)$ or computed radiographaphy, no longer using conventional radiographs such as previous studies. Irregularities or wide discrepancies in the area of the X-ray beam are evaluated by evaluating the firm boundary of the line formed by the $X$-axis and $Y$-axis, then determining the midpoint between the line boundary and the radiation boundary of the scatter. The deviation results concluded that there was no deviation at the central point of $X$-ray beam for all $X$-ray aircraft tested by all aircraft still within the tolerance threshold $=3^{\circ}$. But for the value of the collimator area all the $X$-ray macine tested has deviations exceeding the predefined $2 \%$ FFD threshold where the radiologie france plane occurs deviation on the Y axis with FFD 90 $\mathrm{Cm}$ and $80 \mathrm{Cm}$, hyundai medicaly $X$-ray on $X$ axis with FFD $100 \mathrm{Cm}$ and $80 \mathrm{Cm}, Y$ axis with FFD $80 \mathrm{Cm}$, and on villa sistei medicali SpA plane on $X$ axis with FFD $80 \mathrm{Cm}$, Y axis at FFD $80 \mathrm{Cm}$.
\end{abstract}

Keywords : X-ray beam, computed radiographaphy, X-ray macine, Focus Film Distance.

\begin{abstract}
ABSTRAK
Pengujian kolimator merupakan salah satu program Quality Control (QC) pesawat sinar-X, salah satu pengujian berkas titik pusat dan luas berkas kolimator dengan menggunakan unit RMI. Tujuan pengujian kolimator adalah untuk mengetahui kesesuaian luas lapang kolimator dengan luas lapang berkas sinar-X dalam toleransi $\leq 2 \%$ Focus Film Distance (FFD) dan kesesuaian berkas titik pusat sinar-X dalam toleransi $=3^{\circ}$ yang telah ditentukan oleh Keputusan Menteri Kesehatan No. 1250/SK/XII/2009. Penelitian dilakukan menggunakan variasi FFD pada jarak $100 \mathrm{Cm}, 90 \mathrm{Cm}, 80 \mathrm{Cm}$, pada tiga pesawat sinar-X diinstalasi radiologi RSUD Raden Matther Jambi. Dalam penelitian ini menggunakan unit radiograf digital (DR) atau computed radiogrhaphy, tidak lagi menggunakan radiograf konvesional seperti penelitian-penelitian sebelumnya. Penyimpangan atau ketidaksesuaian luas lapang kolimator dengan luas lapang berkas sinar-X dilakukan dengan cara mengevaluasi batas tegas garis yang dibentuk oleh sumbu X dan sumbu $Y$, kemudian menentukan titik tengah antara batas tegas garis dan batas radiasi hambur. Hasil penyimpangan disimpulkan bahwa tidak terjadi penyimpangan pada titik pusat berkas sinar-X utuk ketiga pesawat sinar-X yang diuji semua pesawat masih berada dalam ambang batas toleransi $=3^{\circ}$. Tetapi untuk nilai luas kolimator semua pesawat sinar-X yang telah diuji mengalami penyimpangan yang melebihi ambang batas $2 \%$ FFD yang telah ditetapkan dimana pesawat trophy radiologie france terjadi penyimpangan pada sumbu Y dengan nilai FFD $90 \mathrm{Cm}$, dan $80 \mathrm{Cm}$, pesawat hyundai medicaly X-ray pada sumbu X dengan FFD $100 \mathrm{Cm}$ dan $80 \mathrm{Cm}$, sumbu Y dengan nilai FFD $80 \mathrm{Cm}$, dan pada pesawat villa sistei medicali S.p.A pada sumbu X dengan FFD $80 \mathrm{Cm}$, sumbu Y pada FFD 80 $\mathrm{Cm}$.
\end{abstract}

Kata kunci : Sinar-X, computer radiografi, pesawat sinar-X, Focus Film Distance (FFD).

\section{PENDAHULUAN}

Pesawat sinar-X adalah pesawat yang menghasilkan gelombang elektromagnetik frekuensi tinggi (sinar-X) untuk digunakan dalamdiagnostik atau terapi.Sinar-X berenergi tinggi yang mampu menembus objek dan membentuk gambaran pada kaset 
radiografi,sedangkan yang energinya rendah akan diserap oleh bahan objek. Besarnya penyerapan oleh bahan tergantung dari panjang gelombang sinar-X, susunan obyek yang terdapat pada alur berkas sinar-X, dan ketebalan serta kerapatanbahan.

Uji Kesesuaian (Compliance Testing) adalah uji untuk memastikan bahwa pesawat Sinar-X memenuhi persyaratan keselamatan radiasi dan memberikan informasi diagnosis atau pelaksanaan radiologi yang tepat dan akurat [1]. Uji kesesuaian merupakan dasar dari suatu program jaminanmutu radiologi diagnostik yang mencakup sebagian tes program jaminan mutu, khususnya parameter yang menyangkut keselamatan radiasi. Tujuan utama Program Jaminan Kualitas (Quality Assurance Program) pada Instalasi Radiologi adalah diagnosa pasien yang tepat dan akurat. Tujuan ini akan terkait dengan program jaminan kualitas menyeluruh yang disesuaikan dengan kebutuhan fasilitas yang mencakup 3 (tiga) hal, yaitu: mengurangi paparan radiasi, peningkatan citra diagnostik dan siasat penekanan biaya [2].

Pada penelitian ini penulis menguji pesawat sinar- $\mathrm{X}$ dengan tiga variasi jarak tabung dengan kaset (FFD) yaitu, $80 \mathrm{~cm}, 90$ $\mathrm{cm}$, dan $100 \mathrm{~cm}$. Pengujian dilakukan pada tiga pesawat $X$-Ray yang tersedia diinstalasi radiologi RSUD Raden Mattaher. Penelitian ini dilakukan untuk memastikan pesawat sinar$\mathrm{X}$ yang tersedia diinstalasi radiologi masih berada pada ambang batas atau telah melewati ambang batas yang ditetapkan oleh Keputusan Menteri Kesehatan No. 1250/SK/XII/2009. Uji kesesuaian ini seharusnya dilakukan secara rutin minimal enam bulan sekali, tetapi pesawat yang ada diinstalasi radiologi RSUD Raden Mattaher sangat jarang dilakukan pengujian satu atau dua tahun sekali pengujian yang dilakukan oleh BATAN menyebabkan pernah terjadinya kesalahan diagnosa pada hasil film radiografi sehingga berakibat fatal pada pendiagnosaan penyakit. Sehingga menjadi salah satu faktor peneliti ingin melakukan uji kesesuaian pada pesawat sinar$\mathrm{X}$ diinstalasi radiologi.

\section{METODE}

\section{Bahan penelitian}

Adapun alat yang digunakan pada penelitian kali ini adalah tiga pesawat sinar-X, tropy radiologie france, hyundai medicaly $\mathrm{x}$ ray, dan villa sistemi medical S.p.A, unit RMI colimator test tool dan beam alighment test tool, computed radiografi, imaging plate, dan waterpass.

\section{Pengambilan citra radiografi}

Pengambilan citra radiografi dilakukan dengan persiapan alat beam alighment tes tool dan colimator test tool ditempatkan diatas imaging plate tanpa adanya kemiringan kemudian diatur jarak antara tabung dan kaset atau imaging plate setinggi $80 \mathrm{Cm}$, tempatkan kaset dan unit RMI colimator tes tool dan beam alighment tes tool dibawah penyinaran pesawat sinar-X yang digunakan kemudian dilakukan pengambilan citra radiografi.

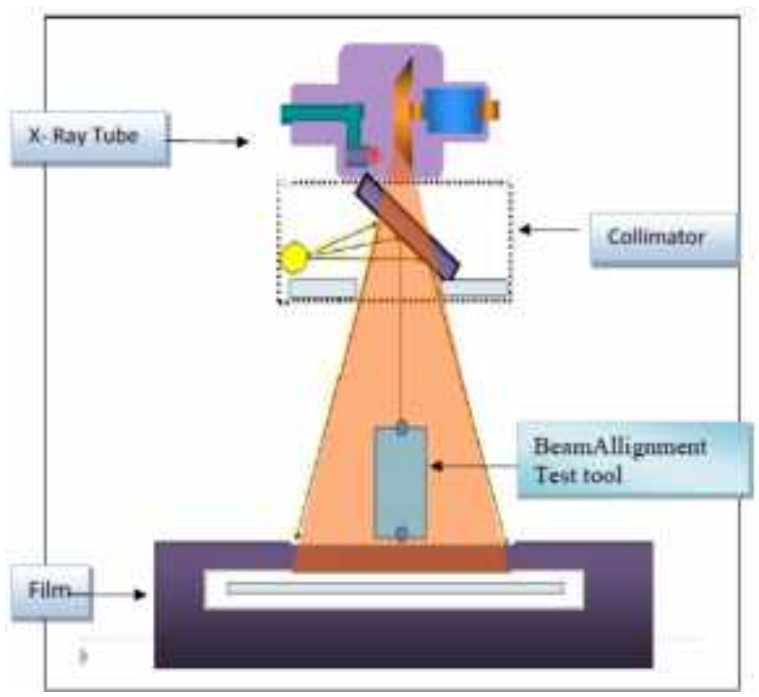

Gambar 1. Skema Uji Kesesuaian Titik Pusat Berkas Sinar- X [1].

\section{Perhitungan nilai penyimpangan}

Nilai penyimpangan untuk titik pusat berkas sinar-X dan luas kolimator dapat dilakukan perhitungan setelah didapatkan hasil citra radiografi dari setiap FFD yang digunakan pada tiga pesawat sinar-X yang 
diuji, kemudian dilakukan pengukran panjang penyimpangan menggunakan computer radiografi, dan dilakukan perhitungan menggunakan persamaan yang ditetapkan oleh kementerian kesehatan No.1250/SK/XII/2009 [3].

\section{Metode analisa}

\section{Luas lapang kolimator sinar-X}

Data yang dihasilkan dalam bentuk digital radiografi kemudian dievaluasi dengan melihat batas tegas garis yang dibentuk oleh sumbu $\mathrm{X}$ dan sumbu Y. Perhitungan penyimpangan luas kolimator untuk sumbu $\mathrm{X}$ dan sumbu $\mathrm{Y}$ ditentukan melalui perhitungan:

$$
\begin{aligned}
& \mathrm{X}_{1}+\mathrm{X}_{2} \leq 2 \% \mathrm{FFD} \\
& \mathrm{Y}_{1}+\mathrm{Y}_{2} \leq 2 \% \mathrm{FFD}
\end{aligned}
$$

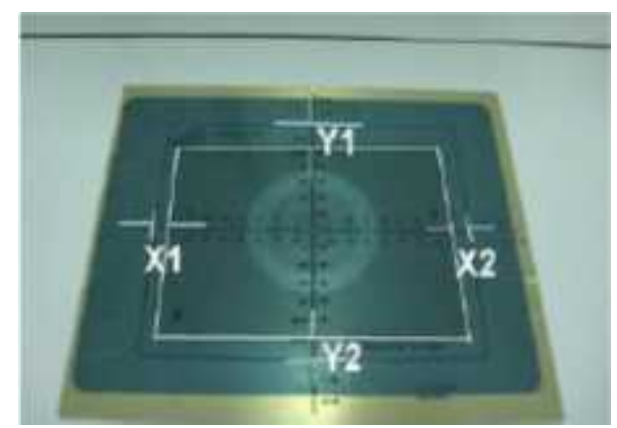

Gambar 2. Pengujian Berkas Kolimator Sinar-X [3].

\section{Titik pusat berkas sinar-X}

Hasil citra yang didapatkan untuk menentukan titik tengah antara batas tegas garis dan batas radiasi hambur nilai penyimpangan titik tengah atau dapat ditentukan melalui perhitungan:

$$
\theta=\tan ^{-1}\left[\begin{array}{cc}
r(F \quad-h-x) \\
\hline F & (h+x)
\end{array}\right]
$$

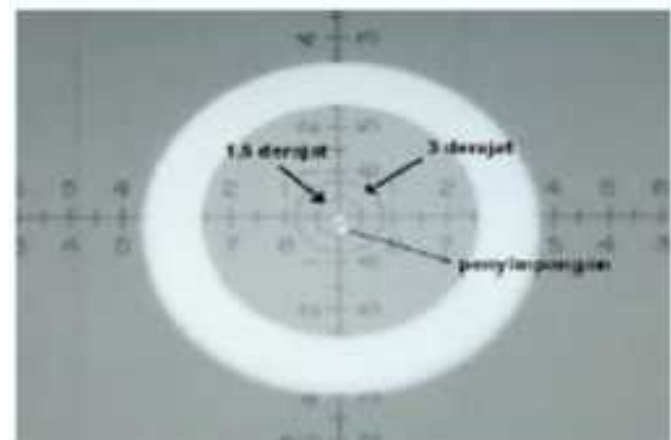

Gambar 3. Penyimpangan titik pusat berkas Sinar-X [4].

\section{Analisa data}

Percobaan ini menggunakan prosedur yang telah ditetapkan oleh kementerian kesehatan No.1250/SK/XII/ 2009 dengan perlakuan pada tiga merk pesawat yang diulang sebanyak 3 kali pengambilan citra dengan variasi jarak atau FFD yang berbeda [3].

\section{HASIL DAN PEMBAHASAN}

\section{Penyimpangan berkas titik pusat sinar-X}

Dalam penelitian ini untuk menentukan ketepatan titik pusat berkas sinar-X batas toleransi yang ditetapkan oleh Radiation safety Act 1975, Diagnostic X-Ray Uquipment Compliance Test 2000 serta National Council on Radiation Protection and Measurment (NCRP) yaitu $\leq 3^{\circ}$. Dimana pada Collimator test tool sudah diketahui jarak antara pusat berkas sinar-X dan lingkaran kecil $4 \mathrm{~mm}(0,4$ $\mathrm{cm})$ pada kemiringan $1,5^{\circ}$, sedangkan lingkaran besar dengan jarak $8 \mathrm{~mm}(0,8 \mathrm{~cm})$ pada kemiringan $3^{0}[5]$.

Dari hasil pengukuran citra beam radiografi dari Beam Alighnment dengan variasi FFD $100 \mathrm{Cm}, 90 \mathrm{Cm}, 80 \mathrm{Cm}$ dengan menggunakan persamaan 4, maka diperoleh hasil pada tabel 1 . 
Tabel 1. Hasil penyimpangan titik pusat berkas sinar-X.

\begin{tabular}{cccc}
\hline Jenis Pesawat & & FFD & \\
& $100 \mathrm{~cm}$ & $90 \mathrm{~cm}$ & $80 \mathrm{~cm}$ \\
\hline $\begin{array}{c}\text { Trophy } \\
\text { Radiologie } \\
\text { France }\end{array}$ & $0,95^{\circ}$ & $0,74^{\circ}$ & $0,26^{\circ}$ \\
$\begin{array}{c}\text { Hyundai } \\
\text { Medicaly X-Ray } \\
\text { Villa Sistemi }\end{array}$ & $0,81^{\circ}$ & $1,48^{\circ}$ & $0,06^{\circ}$ \\
Medicali S.p.A & $1,44^{\circ}$ & $1,09^{\circ}$ & $0,46^{\circ}$ \\
\hline
\end{tabular}

Dari tabel 1 dapat dilihat bahwa uji kesesuaian untuk berkas titik pusat pada pesawat sinar-X yang ada diinstalasi radiologi RSUD Raden Mattaher jambi masih berada dalam ambang batas ketentuan oleh kemenkes yaitu $\leq 3^{\circ}$.

Hasil yang didapat pada pengujian tidak ada yang melebihi $3^{\circ}$, nilai yang didapat kan untuk pesawat Trophy Radiologie France pada FFD $100 \mathrm{Cm}=0,95^{\circ}$, FFD $90 \mathrm{Cm}=0,74^{\circ}$, FFD $80 \mathrm{Cm}=0,26^{\circ}$, untuk pesawat Hyundai Medicaly X-Ray pada FFD $100 \mathrm{Cm}=0,81^{\circ}$, FFD $90 \mathrm{Cm}=1,48^{\circ}$, FFD $80 \mathrm{Cm}=0,06^{\circ}$, dan untuk pesawat Villa Sistemi Medicali S.p.A pada FFD $100 \mathrm{Cm}=1,44^{\circ}$, FFD $90 \mathrm{Cm}=$ $1,09^{\circ}$, FFD $80 \mathrm{Cm}=0,46^{\circ}$. Untuk nilai tertinggi penyimpangan berkas titik pusat yang didapat kan yaitu pada pesawat Hyundai Medicaly X-Ray $=1,48^{\circ}$ pada FFD $90 \mathrm{Cm}$ dan nilai terendah pada FFD $80 \mathrm{Cm}$ dengan $=0,06^{\circ}$.

Dari grafik yang terbentuk dapat dilihat bahwa semakin besar FFD maka nilai penyimpangan atau akan semakin bertambah, begitu pula sebaliknya semakin kecil FFD nilai yang didapatkan akan semakin berkurang. Pada grafik diatas dapat dilihat pada FFD $90 \mathrm{Cm}$ pesawat hyundai terjadi perbedaan nilai yang sangat signifikan dimana dari nilai $0,81^{\circ}$ meningkat menjadi $1,48^{\circ}$ dan turun kembali menjadi $0,06^{\circ}$ hal ini dapat disebabkan oleh tidak mampunya daya pesawat mendapatkan titik fokus pada jarak 90 $\mathrm{Cm}$ dan menurunnya kualitas pesawat sinar-X yang disebabkan oleh tidak mampunya pesawat dalam menghasilkan sinar-X dan menurunnya kemampuan katup colimator pesawat sinar-X dalam mengatur jumlah sinar-X yang dikeluarkan yang menyebabkan terjadinya penyimpangan. Namun penyimpangan berkas titik pusat pada pesawat hyundai masih berada dalam ambang batas ketentuan yaitu $\leq 3^{\circ}$.

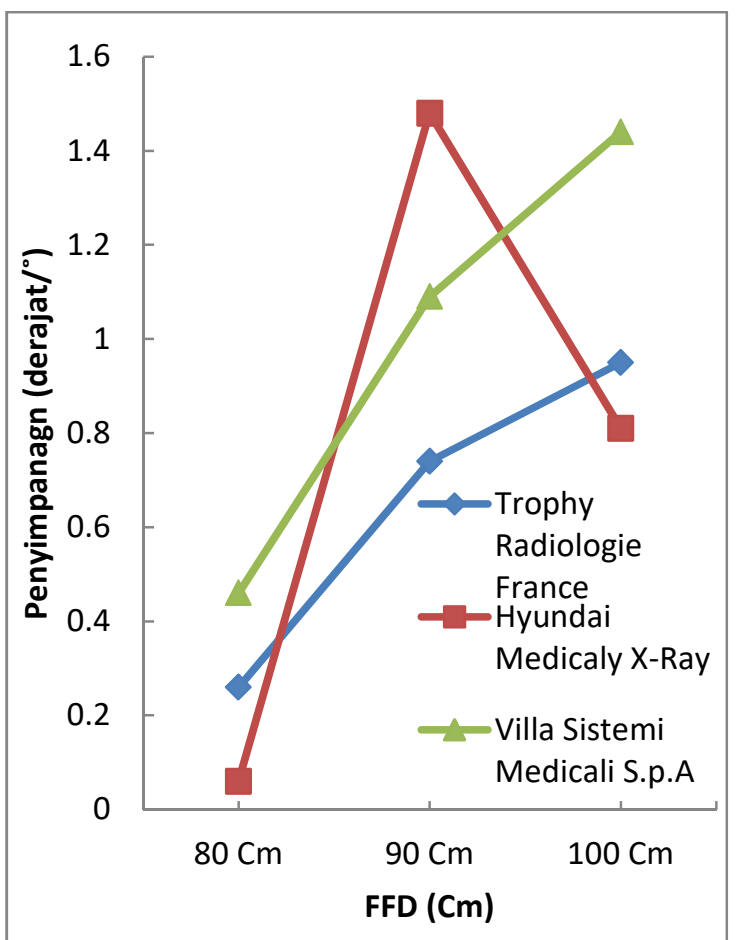

Gambar 4. Grafik penyimpangan berkas titik pusat sinar-X.

Sehingga dapat di katakan untuk uji ketepatan titik pusat pada tiga pesawat sinar-X semakin besar jarak yang diberikan pada saat pengambilan citra radiografi maka nilai penyimpangan titik pusat pesawat sinar-X juga akan semakin bertambah, namun dalam pengujian pada pesawat sinar-X diinstalasi radiologi RSUD Raden Mattaher Jambi masih berada dalam ambang batas normal atau aman untuk digunakan dan sesuai dengan keputusan menteri kesehatan No. 1250/SK/XII/2009 bahwa nilai untuk setiap pesawat sinar-X yang boleh digunakan yaitu $\leq 3^{\circ}[3]$. 
Tabel 2. Hasil uji kesesuaian luas kolimator pesawat sinar-X.

\begin{tabular}{cccccc}
\hline \multirow{2}{*}{ Jenis Pesawat } & & & FFD & & Uji \\
& & $100 \mathrm{Cm}$ & $90 \mathrm{Cm}$ & $80 \mathrm{Cm}$ & kesesuaian \\
\hline \multirow{2}{*}{ Trophy Radiologie France } & $\mathrm{X} 1+\mathrm{X} 2$ & $0,5 \mathrm{Cm}$ & $0,6 \mathrm{Cm}$ & $0,9 \mathrm{Cm}$ & $\sqrt{ }$ \\
& $\mathrm{Y} 1+\mathrm{Y} 2$ & $2 \mathrm{Cm}$ & $2,1 \mathrm{Cm}$ & $2,7 \mathrm{Cm}$ & $\mathrm{X}$ \\
& $\mathrm{X} 1+\mathrm{X} 2$ & $2,5 \mathrm{Cm}$ & $0,2 \mathrm{Cm}$ & $3 \mathrm{Cm}$ & $\mathrm{X}$ \\
Hyundai Medicaly X-Ray & $\mathrm{Y} 1+\mathrm{Y} 2$ & $0,4 \mathrm{Cm}$ & $0 \mathrm{Cm}$ & $2 \mathrm{Cm}$ & $\mathrm{X}$ \\
Villa Sistemi Medicali & $\mathrm{X} 1+\mathrm{X} 2$ & $1,4 \mathrm{Cm}$ & $1,6 \mathrm{Cm}$ & $2 \mathrm{Cm}$ & $\mathrm{X}$ \\
& $\mathrm{Y} 1+\mathrm{Y} 2$ & $1 \mathrm{Cm}$ & $1,4 \mathrm{Cm}$ & $2,2 \mathrm{Cm}$ & $\mathrm{X}$ \\
& Toleransi & $2 \mathrm{Cm}$ & $1,8 \mathrm{Cm}$ & $1,6 \mathrm{Cm}$ & \\
\hline
\end{tabular}

\section{Penyimpangan luas kolimator sinar-X}

Dari tabel 2 dapat dilihat bahwa pada uji kesesuaian luas kolimator pesawat sinar-X dengan toleransi untuk tiap FFD $100 \mathrm{Cm}=2$ $\mathrm{Cm}, 90 \mathrm{Cm}=1,8 \mathrm{Cm}, 80 \mathrm{Cm}=1,6 \mathrm{Cm}$.

Gambar 5 menunjukkan grafik penyimpangan pada pesawat tropy radiologie france dimana penyimpangan terjadi pada sumbu $\mathrm{Y}$ yang telah melebihi ambang batas $2 \%$ dari FFD yang diberikan oleh kemenkes yaitu pada FFD $80 \mathrm{Cm}=2,7 \mathrm{Cm}, 90 \mathrm{Cm}=2,1$ $\mathrm{Cm}$, dan $100 \mathrm{Cm}=2 \mathrm{Cm}$ sedangkan untuk sumbu X setiap FFD yang diuji pesawat tropy berada dalam ambang batas yang ditentukan $80 \mathrm{Cm}=0,9 \mathrm{Cm}, 90 \mathrm{Cm}=0,6 \mathrm{Cm}$, dan 100 $\mathrm{Cm}=0,5 \mathrm{Cm}$. Sehingga pesawat Trophy Radiologie France ini sesuai ketentuan dari kemenkes jika melebihi 2\% FFD tidak layak untuk digunakan dalam pengambilan citra radiografi. Dari garafik diatas didapatkan penyimpangan pada sumbu $X$ pada FFD 100 $\mathrm{Cm}=2,5 \mathrm{Cm}$, dan $80 \mathrm{Cm}=3 \mathrm{Cm}$ sedangkan pada pada FFD $90 \mathrm{Cm}$ berada dalam ambang batas yang ditentukan, untuk sumbu $\mathrm{Y}$ penyimpangan terjadi pada FFD $80 \mathrm{Cm}=2$
Cm sedangkan untuk FFD $90 \mathrm{Cm}=0,2 \mathrm{Cm}$ dan $100 \mathrm{Cm}=0,4 \mathrm{Cm}$ berada dalam ambang batas normal. Sehingga untuk pesawat Hyundai Medicaly X-Ray masih dapat dilakukan pengambilan citra radiografi hanya pada FFD $90 \mathrm{Cm}$, untuk FFD $100 \mathrm{Cm}$ dan 80 $\mathrm{Cm}$ telah melebihi ambang batas ketentuan yang ditetapkan. Gambar 7 menunjukkan pemyimpangan luas kolimator pada pesawat Villa Sistemi Medicali S.p.A dimana terjadi penyimpangan pada sumbu $X$ pada FFD 80 $\mathrm{Cm}=2 \mathrm{Cm}$ sedangkan pada FFD $100 \mathrm{Cm}=$ $1,4 \mathrm{Cm}$ dan $90 \mathrm{Cm}=1,6 \mathrm{Cm}$ berada dalam ambang batas yang ditetapkan, untuk sumbu Y penyimpangan juga terjadi pada FFD $80 \mathrm{Cm}=$ 2,2 Cm sedangkan pada FFD $100 \mathrm{Cm}=1 \mathrm{Cm}$ dan $90 \mathrm{Cm}=1,4 \mathrm{Cm}$ berada dalam ambang batas. Sehingga didapatkan untuk pesawat Villa Sistemi Medicali S.p.A dapat dipergunakan untuk pengambilan citra radiografi pada FFD $100 \mathrm{Cm}$ dan $90 \mathrm{Cm}$ karena tidak terjadinya penyimpangan yang melebihi ambang batas yang ditetapkan oleh kemenkes. 


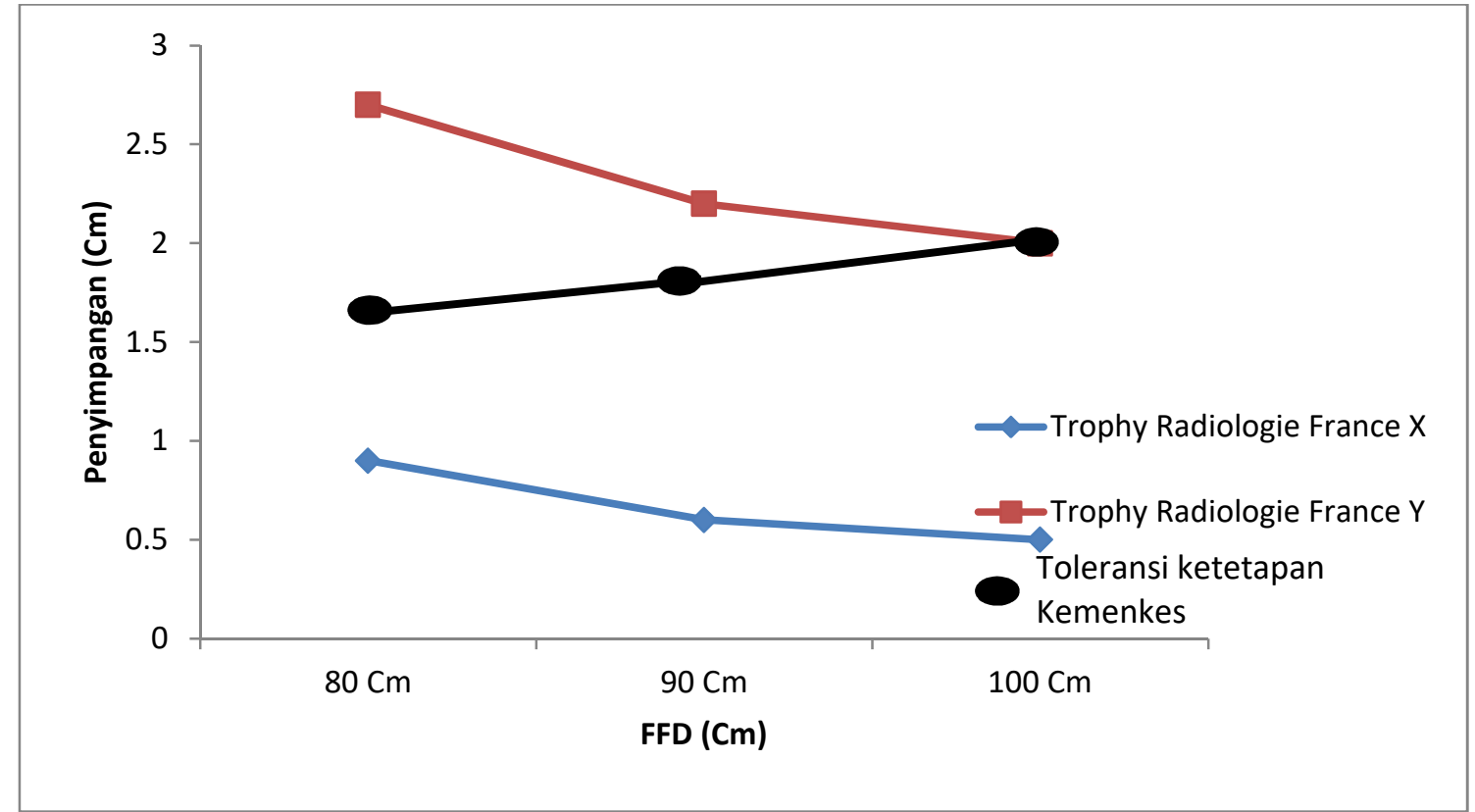

Gambar 5. Grafik penyimpangan luas kolimator pada pesawat Trophy Radiologie France.

Dari hasil pengujian yang telah dilakukan untuk luas kolimator pada tiga pesawat sinar-X diinstalasi radiologi RSUD Raden Mattaher Jambi didapatkan terjadinya kemiringan luas kolimator pada ketiga pesawat sinar-X yang dilakuakn pengujian rata-rata kemiringan yang terjadi berada pada jarak FFD $80 \mathrm{Cm}$ yaitu jarak terkecil yang diberikan pada pengujian, sedangkan untuk FFD $100 \mathrm{Cm}$ hanya terjadi kemiringan pada pesawat Hyundai Medicaly
$X$-Ray. Variasi jarak FFD yang diberikan sangat berpengaruh pada pengujian berkas kolimator pada pesawat sinar-x, dikarenakan semakin kecil FFD atau jarak yang diberikan maka nilai-nilai kemiringan luas kolimator akan semakin besar begitu pula sebaliknya semakin besar FFD yang diberikan nilai kemiringan luas kolimator akan semakin mengecil.

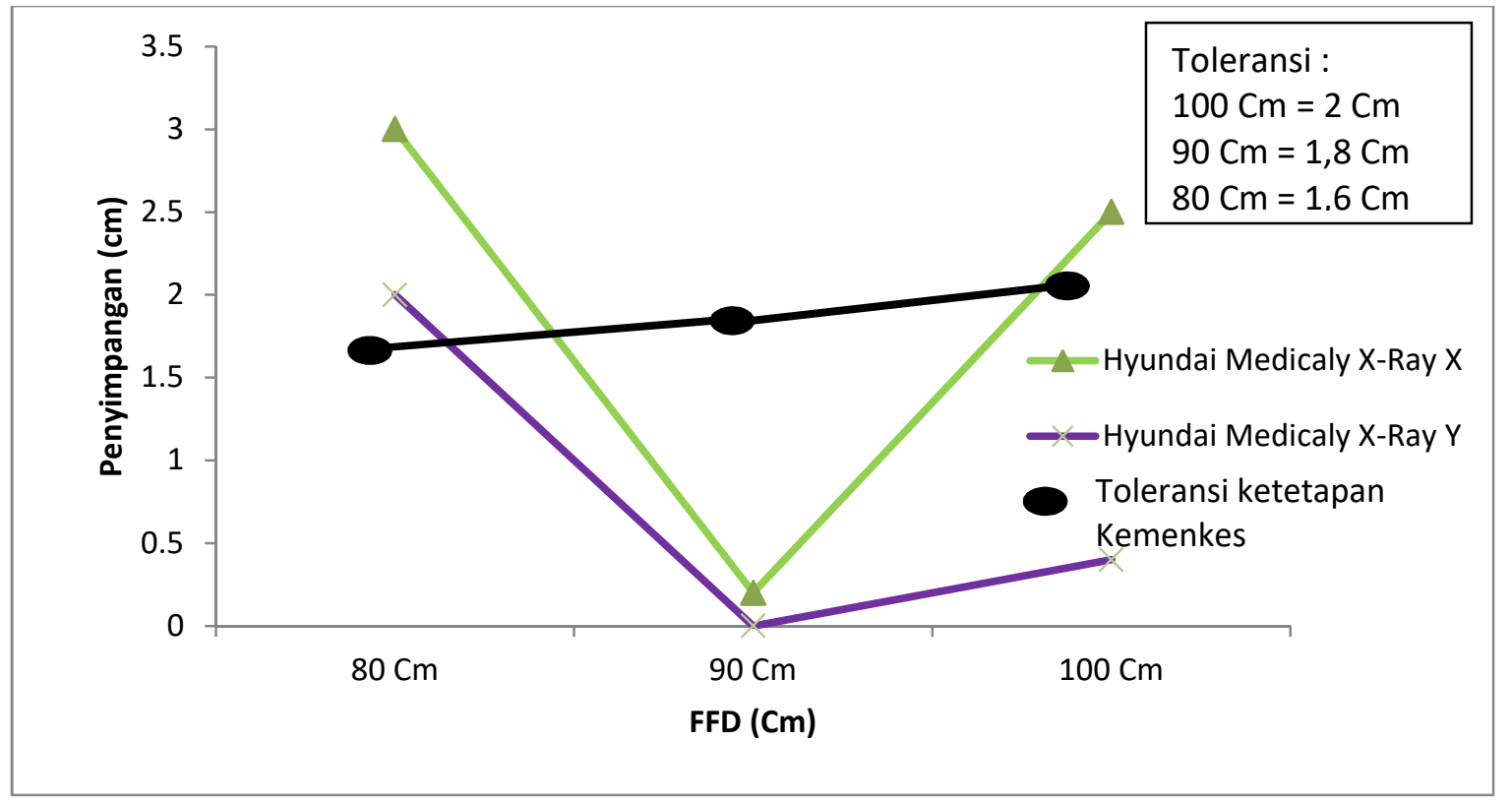

Gambar 6. Grafik penyimpangan luas kolimator pesawat Hyundai Medicaly X-Ray. 


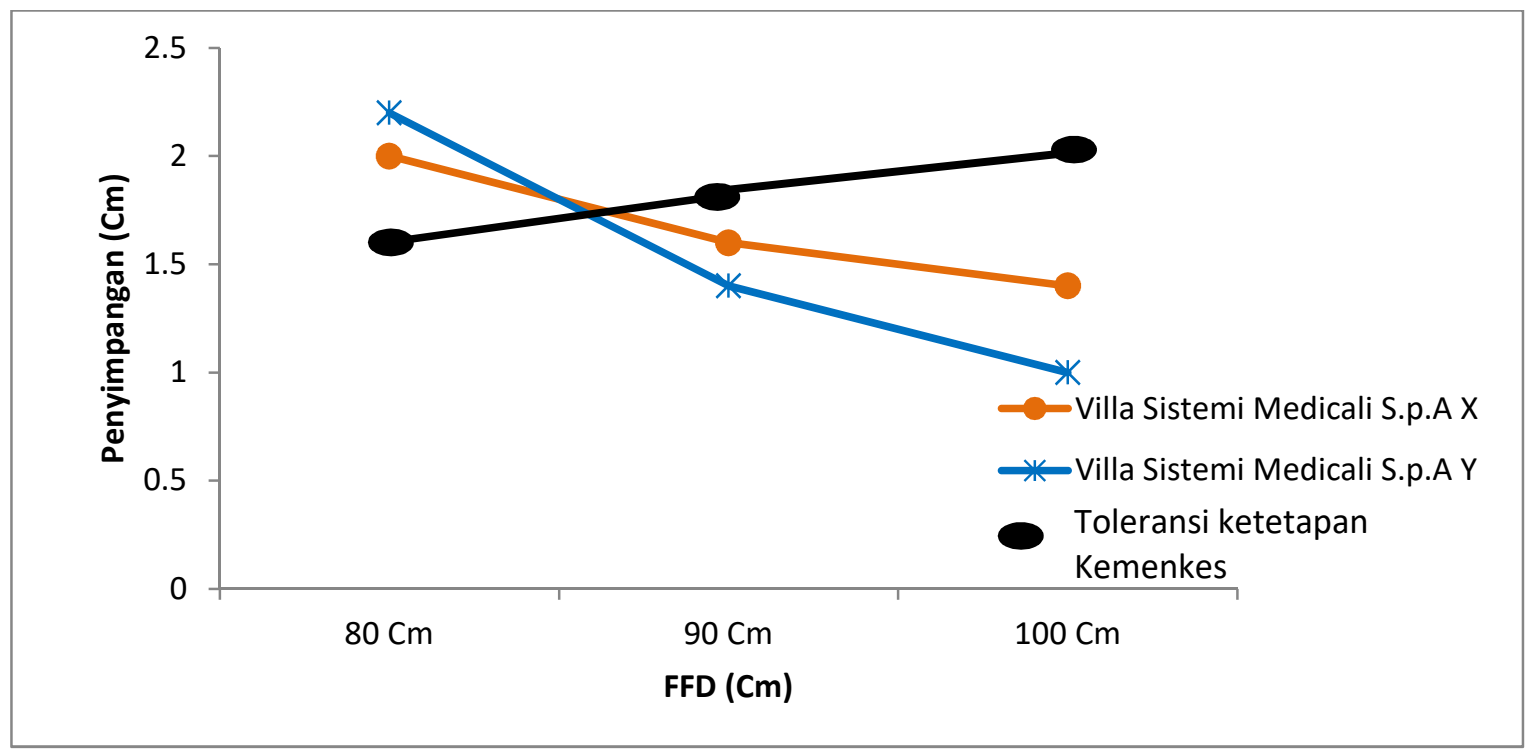

Gambar 7. Grafik penyimpanganluas kolimator pada pesawat Villa Sistemi Medicali S.p.A.

\section{KESIMPULAN}

Berdasarkan Hasil uji kesesuaian yang telah dilakukan membuktikan bahwa pada ketiga pesawat sinar-X diinstalasi radiologi untuk nilai ketepatan titik pusat berkas sinar-X semua pesawat masih berada dalam ambang batas ketentuan kemenkes nilai tertinggi yang didapatkan pada pesawat hyundai medicaly XRay dengan FFD $90 \mathrm{Cm}=1,48^{\circ}$ nilai tersebut tidak melebihi ketentuan $\leq 3^{\circ}$. Tetapi untuk nilai luas kolimator semua pesawat sinar-X yang telah diuji mengalami penyimpangan yang melebihi ambang batas $2 \%$ FFD yang telah ditetapkan dimana pesawat trophy radiologie france terjadi penyimpangan pada sumbu Y dengan nilai FFD $90 \mathrm{Cm}$, dan $80 \mathrm{Cm}$, pesawat hyundai medicaly $\mathrm{X}$-ray pada sumbu $\mathrm{X}$ dengan FFD $100 \mathrm{Cm}$ dan $80 \mathrm{Cm}$, sumbu Y dengan nilai FFD $80 \mathrm{Cm}$, dan pada pesawat villa sistei medicali S.p.A pada sumbu $\mathrm{X}$ dengan FFD $80 \mathrm{Cm}$, sumbu Y pada FFD 80 $\mathrm{Cm}$.

\section{DAFTAR PUSTAKA}

1. Chadidjah, S. (2012). Penentuan ketepatan titik pusat berkas sinar Pada pesawat mobile X-Ray sebagai parameter Kualitas kontrol di rsud. Prof. Dr. Hm. Anwar
Makkatutu bantaeng. Skripsi. Makassar: FMIPA Universitas Hasanuddin.

2. Dwi, K. S. (2008). Workshop Tentang Batas Toleransi Pengukuran Uji Kesesuaian Pesawat Sinar-X. Fisika Universitas Indonesia.

3. Depkes. (2009). Keputusan Menteri Kesehatan Republik Indonesia Nomor 1250/MENKES/SK/XII/2009 tentang Pedoman Kendali Mutu (Quality Control) Peralatan Radio diagnostik. Website:http://www.hukor.depkes.go.id/u p_prod_kepmenkes/KMK\%20No.\%20125 0\%20ttg\%20Kendali\%20Mutu\%20Radiod iagnostik.pdf. Diakses tanggal 27 Maret 2015.

4. Fluke Biomedical. (2005). Nuclear Associates 07-661-7662 Collimator/ Beam Alignment Test Tool. U.S.A: Fluke Corporation.

5. Radiation Safety ACT. (1975). Diagnostic $X$ - Ray Equipment Compliance Testing. Regulation For the Administration and Enforcement Of the Radiation Control Health and Safety. 